\title{
Fetal head circumference versus fetal weight at term as a predictor of labour outcome
}

\author{
Nishita Shettian, Nikita Pitty* \\ Department of Obstetrics and Gynaecology, AJ institute of Medical Sciences and Research Centre, Mangalore, \\ Karnataka, India
}

Received: 04 November 2021

Accepted: 25 November 2021

*Correspondence:

Dr. Nikita Pitty,

E-mail: nikitapitty@gmail.com

Copyright: $\odot$ the author(s), publisher and licensee Medip Academy. This is an open-access article distributed under the terms of the Creative Commons Attribution Non-Commercial License, which permits unrestricted non-commercial use, distribution, and reproduction in any medium, provided the original work is properly cited.

\begin{abstract}
Background: Several models have been proposed to predict the need for an LSCS. With reference to this, the impact of the size of the fetal head traversing the birth canal is an important determinant of delivery outcomes. We examined the association between the head circumference and mode of delivery and perinatal outcomes, when compared to birth weight predicted by scan.

Methods: This was a retrospective study, on 800 electronic delivery records between December 2019 and May 2021. Sociodemographic data, obstetrical parameter, term scan findings of head circumference and estimated fetal weight, and labour and perinatal outcomes were collected and analysed.

Results: $\mathrm{HC}>95^{\text {th }}$ centile was found to be comparatively more predictive and statistically significant compared to EFW $>95^{\text {th }}$ centile in the prediction of LSCS, with the most common indication being cephalopelvic disproportion. Prolonged second stage of labour was statistically significant in both cohort A and B, undergoing vaginal delivery. It was also noted that a significant number of newborns in cohort A required NICU admissions, while NICU admissions after emergency LSCS was significantly higher in the cohort B $(\mathrm{p}=0.0032)$ though the overall 5 and 10 minute APGAR scores and duration of stay were comparable in the groups classified on basis of EFW and HC.

Conclusions: The above statistics observed on an Indian population may aid obstetricians in the planning of the mode of delivery, improve pre-labor counselling and efficient management of mothers of large babies.
\end{abstract}

Keywords: Indian population, Head circumference, Estimated- fetal weight, Term scan, Labour outcomes

\section{INTRODUCTION}

An uncomplicated vaginal delivery is the desire of every obstetrician and her parturient. LSCS is the surgical procedure indicated in situations where the vaginal delivery presents a higher likelihood of adverse maternal and/or fetal outcome. But when compared to vaginal delivery, Caesarean section has shown to increase the prevalence of maternal morbidity and mortality ${ }^{1}$. Hence many predictive models have been proposed to foresee a possible LSCS to facilitate early referral to a center where it can be performed, to considerably reduce maternal morbidity (perineal tears, postpartum hemorrhage, obstetric fistulae etc) and neonatal morbidity (birth asphyxia and birth trauma). Besides maternal BMI, maternal age, ethnicity, mode of previous delivery, presence of hypertensive disorders of pregnancy, diabetes, multiple gestations etc, several anthropometric measurements like height, bisacromial, intercristal, intertrochanteric diameters, foot length, vertical and transverse diameters of the Michaelis rhomboid, symphysiofundal height and abdominal girth may help to predict mode of delivery. ${ }^{2-5}$ While these factors predict the association of "passage" or the maternal factors that determine the labour outcome several studies have also evaluated the "passenger" or the fetal factors to predict 
the association of mode of delivery namely the associations of sonographic estimation of fetal weight and head circumference with progress of labour or caesarean delivery. ${ }^{6-9}$ The objective of this paper is to evaluate the accuracy of estimated fetal weight and head circumference noted on the ultrasound scan done at term to predict labour outcome.

\section{METHODS}

This a retrospective study carried out in the department of obstetrics and gynaecology at A.J institute of medical sciences among women who delivered between December 2019 and May 2021. A total of 800 electronic records were reviewed in the study.

\section{Inclusion criteria}

Inclusion criteria for given study were; women with singleton pregnancy between 18 to 40 years of age delivered between 37 to 42 weeks of gestation.

\section{Exclusion criteria}

Exclusion criteria for given study were; Age less that 18 years or more than 40 years, incomplete data and non availability of ultrasound scan at term gestation. Data collected was entered in Microsoft excel under the following headings: maternal demographic details, obstetric parameters - parity, type of delivery, $2^{\text {nd }}$ stage duration, use of vaccum/foreceps, indication for LSCS, Ultrasound scan findings- gestational age, head circumference, estimated fetal weight and neonatal parameters like 5 and 10 minute APGAR scores, NICU admission and duration of stay. The participants were then grouped into subgroups based on estimated fetal weight $>95^{\text {th }}$ centile - Cohort A and compared with those with estimated fetal weight $<95^{\text {th }}$ centile, birth weight, mode of delivery, intraoperative findings and new born parameters. Similarly, the participants were grouped into cohort $\mathrm{B}$, those with head circumference $>95^{\text {th }}$ centile and compared for the above stated parameters with those with head circumference $<95^{\text {th }}$ centile. The findings were analyzed using descriptive statistics like frequencies, percentages and measures of central tendencies. The predictive value of $\mathrm{EFW}>95^{\text {th }}$ centile and $\mathrm{HC}>95^{\text {th }}$ centile were given in the form of sensitivity, specificity, PPV, NPV and accuracy in anticipating mode of delivery.

\section{RESULTS}

The data of 800 study samples were collected. The results were analysed according to the following parameters.

\section{Sociodemographic details of the mother}

The age of the mothers ranged between 20 and 35 years (Table 1). The youngest patient in the study was 21 years. An elderly primigravida aged 39 years was included.

While assessing the pre-pregnancy weights of the mothers, it was noted that $49 \%$ had normal BMI, and no women in the study was morbidly obese. The proportion of the religions of the mothers surveyed and it almost corresponds to the distribution within the population is shown in (Table 1).

Table 1: Sociodemographic details of study participants.

\begin{tabular}{|ll|}
\hline Parameter & Percentage of participants \\
\hline Age range (years) & \\
\hline $20-25$ & 43 \\
\hline $26-30$ & 50 \\
\hline BMI & \\
\hline Under weight & 20 \\
\hline Normal & 49 \\
\hline Overweight & 25 \\
\hline Obese & 6 \\
\hline Extremely obese & 0 \\
\hline Educational status & \\
\hline Informal education & 18 \\
\hline Primary school & 25 \\
\hline Middle school & 12.5 \\
\hline High school & 10 \\
\hline Intermediate/diploma & 25 \\
\hline Graduate & 9.5 \\
\hline Employment status & \\
\hline Unemployed & 95 \\
\hline Employed & 5 \\
\hline Socioeconomic status & \\
\hline Class 1 & 1.5 \\
\hline Class 2 & 6 \\
\hline Class 3 & 36 \\
\hline Class 4 & 46 \\
\hline Booking status & 97 \\
\hline Booked & \\
\hline Unbooked & \\
\hline
\end{tabular}

While a small section of the mothers have received only informal education, almost $57 \%$ have been educated beyond middle school and $5 \%$ of the women were employed. The mothers were categorized according to modified BG Prasad classification as they belonged to both rural and urban backdrops. It was noticed that majority of the mothers belonged to class 4- upper middle class.97\% of the mothers had their regular antenatal check-ups at our hospital. Parity: $38 \%$ of the mothers in the study were primiparas (Table 2).

\section{Ultrasound parameters}

Estimated fetal weight by term scan: total 12 percent of the fetuses were below the $5^{\text {th }}$ centile for EFW for the corresponding weeks of gestation on term scan while $28 \%$, that is 224 fetuses were above the $95^{\text {th }}$ centile as per the Indian parameters as shown in (Table 3). 
Table 2: Sociodemographic details of study participants.

\begin{tabular}{|l|l|}
\hline Parity & Percentage \\
\hline Primigravida & 38 \\
\hline Multigravida & 62 \\
\hline
\end{tabular}

Table 3: Distribution of foetuses based on EFW by term scan according to Indian parameters corresponded to period of gestation.

\begin{tabular}{|ll|}
\hline EFW Percentile as per scan & Percentage \\
\hline$\leq \mathbf{5}^{\text {th }}$ centile & 12 \\
\hline Mean & 60 \\
\hline$>\mathbf{9 5}^{\text {th }}$ centile & 28 \\
\hline
\end{tabular}

\section{Head circumference by term scan}

It was noted that by the term scan 12 percent of the fetuses fell below the $5^{\text {th }}$ centile for head circumference taken as per the Indian parameters for the corresponding period of gestation, in comparison to $32 \%$ ie 256 fetuses, who were above the $95^{\text {th }}$ centile for the same (Table 4).

Table 4: Distribution of foetuses based on HC by term scan according to Indian parameters corresponded to period of gestation.

\begin{tabular}{|ll|}
\hline HC Percentile as per scan & Percentage \\
\hline $\mathbf{5}^{\text {th }}$ centile & 12 \\
\hline Mean & 56 \\
\hline$>\mathbf{9 5}^{\text {th }}$ centile & 32 \\
\hline
\end{tabular}

\section{Comparison between the intrapartum, labour and newborn outcome between the cohorts}

It has been noted in Table 5 that $32 \%$ of Cohort A (i.e. those with $\mathrm{EFW}>95^{\text {th }}$ centile) underwent caesarean section, with the most common indication being cephalopelvic disproportion in $52 \%$, followed by failed induction and fetal distress. $28 \%$ of the participants underwent caesarean section in the group with EFW $>95^{\text {th }}$ centile. The mode of delivery in the cohort A was statistically not significant when compared with the remaining participants and has a $\mathrm{p}$ value of 0.739 . However among the participants in cohort A those who underwent vaginal delivery a statistically significant number had prolonged 2 nd stage of labour $(\mathrm{p}=0.006)$.It was also noted that a significant number of newborns in cohort A required NICU admissions in comparison to the remainder, though the overall 5 and 10 minute APGAR scores and duration of stay were similar in the 2 groups classified on basis of EFW.

Total $59 \%$ of study participants in cohort B (those with $\mathrm{HC}>95^{\text {th }}$ centile) underwent caesarean section, in comparison to $20 \%$ in the group with $\mathrm{HC}<95^{\text {th }}$ centile, and this finding had a statistically significant $\mathrm{p}$ value of
$<0.00001$ (Table 5). The most common indication for LSCS was cephalopelvic disproportion while 58\% in cohort B who underwent vaginal delivery had prolonged 2nd stage of labour, both of which had a significant $p$ value of $<0.00001$. NICU admissions post an emergency LSCS was significantly higher in the cohort $B(p=0.0032)$ but the overall 5 and 10 minute APGAR scores and duration of stay were comparable in the groups classified on basis of $\mathrm{HC}$.

\section{Comparison of $\mathrm{EFW}>95^{\text {th }}$ centile and $\mathrm{HC}>95^{\text {th }}$ centile by term scan in the prediction mode of delivery}

The sensitivity, specificity, PPV, NPV and accuracy of $\mathrm{EFW}>95^{\text {th }}$ centile was $33 \%, 72 \%, 95.73 \%, 5.35 \%$ and $34.95 \%$ respectively. The sensitivity, specificity, PPV, $\mathrm{NPV}$ and accuracy of $\mathrm{HC}>95^{\text {th }}$ centile was $59 \%, 80 \%$, $98.25 \%, 9.31 \%$ and $60.05 \%$ respectively.

\section{DISCUSSION}

The study sample consisted of participants of similar socio-demographic data in a tertiary care centre in Mangaluru. $38 \%$ of the subjects were primigravidas, and $97 \%$ of the cases were booked with our institution. The participant data was stratified into cohort A those with $\mathrm{EFW}>95^{\text {th }}$ centile for respective period of gestation and compared with the remaining participants for labour and neonatal outcome. A similar comparison was made between cohort $\mathrm{B}$ those with $\mathrm{HC}>95^{\text {th }}$ centile for corresponding weeks of gestation and the rest of the participants. According to a retrospective study by Dunja et al $2^{\text {nd }}$ stage CS were significantly more likely when the EFW was below $2500 \mathrm{~g}$ and was $42.9 \%$ vs. $24.2 \%$ in the normal group. However, a birth weight of $4000 \mathrm{~g}$ or more did not have a significant influence on CS rate. ${ }^{6}$ In the current study we have noted that $32 \%$ of those with EFW $>95^{\text {th }}$ centile in comparison to $28 \%$ in the group with $\mathrm{EFW}<95^{\text {th }}$ centile underwent $\mathrm{CS}$ with the most common indication being CPD. It was noted that among those who underwent vaginal delivery, prolonged $2^{\text {nd }}$ stage of labour ,more than 3 hours was statistically increased among the group with $\mathrm{EFW}>95^{\text {th }}$ centile. It was also significant to note that among Cohort A that underwent emergency CS, the number of newborns requiring NICU admissions were also significantly higher compared to the other group. In another study cohort with 11687 singleton live births grouped into quartiles based on increasing neonatal head circumference, the rates of CS were also noted to increase $4.1 \%, 6.4 \%, 8.8 \%$ and $14.3 \%$, showing a strong positive relationship between head circumference quartile and CS. ${ }^{8}$ in our study we noted a statistical increase in number of $\mathrm{CS}$ in the group with $\mathrm{HC}>95^{\text {th }}$ centile $\mathrm{p}<0.00001$, with the most common indication again being CPD. It is also observed that more number of neonates delivered out of emergency $\mathrm{CS}$ in this group required NICU admission though the duration of stay is comparable. Prolonged $2^{\text {nd }}$ stage of labour was significantly more in Cohort $\mathrm{B}$ than the rest of the participants with $\mathrm{HC}<95^{\text {th }}$ centile. 
Table 5: Comparison between the intrapartum, labour and newborn outcome between the cohorts.

\begin{tabular}{|c|c|c|c|c|c|c|}
\hline Parameter & $\begin{array}{l}\text { EFW }<95^{\mathrm{Th}} \\
\text { centile }(\mathbf{5 7 6}) \\
\%\end{array}$ & $\begin{array}{l}\text { Cohort A with } \\
\text { EFW>95 } \\
\text { centile }(224) \\
\%\end{array}$ & $\begin{array}{l}\text { Chi square } \\
\text { test- p value }\end{array}$ & $\begin{array}{l}\text { HC }<95^{\text {th }} \\
\text { centile } \\
(\mathbf{5 4 4 )} \%\end{array}$ & $\begin{array}{l}\text { Cohort B } \\
\text { with } \mathrm{HC}> \\
95^{\text {th }} \text { centile } \\
(256) \%\end{array}$ & $\begin{array}{l}\text { Chi square } \\
\text { test p value }\end{array}$ \\
\hline \multicolumn{7}{|l|}{ Mode of delivery } \\
\hline Vaginal delivery & 72 & 67 & \multirow{3}{*}{0.739} & 79 & 41 & \multirow{3}{*}{$<0.00001$} \\
\hline Caesarean section & 28 & 32 & & 20 & 59 & \\
\hline Instrumental delivery & 0 & 1 & & 1 & 0 & \\
\hline \multicolumn{7}{|c|}{ Length of $2^{\text {nd }}$ stage in vaginally delivered subjects } \\
\hline Normal & 64 & 45 & \multirow{2}{*}{0.006} & 82 & 42 & \multirow{2}{*}{$<0.00001$} \\
\hline Prolonged $>3 \mathrm{hrs}$ & 36 & 55 & & 18 & 58 & \\
\hline \multicolumn{7}{|l|}{ Indication for LSCS } \\
\hline $\begin{array}{l}\text { Cephalo-pelvic } \\
\text { disproportion }\end{array}$ & 28 & 52 & \multirow{3}{*}{0.000522} & 12 & 71.2 & \multirow{3}{*}{$<0.00001$} \\
\hline Fetal distress & 45 & 21.5 & & 16 & 26 & \\
\hline Failed induction & 27 & 26.5 & & 72 & 2.8 & \\
\hline \multicolumn{7}{|l|}{ Neonatal outcomes } \\
\hline $\begin{array}{l}\text { Good } 5 \text { and } 10 \text { minute } \\
\text { APGAR Score }\end{array}$ & 85 & 82 & 0.567 & 98 & 92 & 0.051 \\
\hline $\begin{array}{l}\text { NICU admissions post } \\
\text { vaginal delivery/ } \\
\text { elective LSCS }\end{array}$ & 6 & 10 & 0.297 & 5 & 6 & 0.756 \\
\hline $\begin{array}{l}\text { NICU admissions post } \\
\text { Emergency LSCS }\end{array}$ & 14 & 26 & 0.03 & 10 & 26 & 0.0032 \\
\hline $\begin{array}{l}\text { Mean NICU stay in } \\
\text { days }\end{array}$ & 2.65 & 5.23 & - & 2.5 & 3.28 & - \\
\hline
\end{tabular}

Table 6: Comparison between the intrapartum, labour and new-born outcome between the cohorts.

\begin{tabular}{|lll|}
\hline Parameter & Value EFW $>\mathbf{9 5}^{\text {th }}$ Centile at 95\% CI & Value HC $>$ 95 $5^{\text {th }}$ Centile at 95\% CI \\
\hline Sensitivity & $33 \%(23.92 \%$ to $43.12 \%)$ & $59 \%(48.71 \%$ to $68.74 \%)$ \\
\hline Specificity & $72 \%(62.13 \%$ to $80.52 \%)$ & $80 \%(70.82 \%$ to $87.33 \%)$ \\
\hline Positive predictive value & $95.73 \%(93.63 \%$ to $97.15 \%)$ & $98.25 \%(97.34 \%$ to $98.85 \%)$ \\
\hline Negative predictive value & $5.35 \%(4.49 \%$ to $6.37 \%)$ & $9.31 \%(7.37 \%$ to $11.70 \%)$ \\
\hline Accuracy & $34.95 \%(28.36 \%$ to $41.99 \%)$ & $60.05 \%(52.90 \%$ to $66.89 \%)$ \\
\hline
\end{tabular}

In a similar study by Lipschuetz et al it was noted that infants with $\mathrm{HC} \geq 95^{\text {th }}$ centile were delivered vaginally in $62 \%$ of the cases, $16 \%$ had an unplanned LCSC and $11.2 \%$ had an instrumental delivery. ${ }^{9}$ In contrast it was noted that infants with $\mathrm{EFW} \geq 95^{\text {th }}$ centile were delivered vaginally in $80.3 \%$ of the cases, $10.2 \%$ had an unplanned LCSC and $8.2 \%$ had an instrumental delivery. Multinomial regression analysis showed that large HC/normal EFW were more likely to undergo unplanned LSCS or instrumental delivery. It was found in our study that the statistical accuracy of $\mathrm{HC}>95^{\text {th }}$ centile is comparatively more that of $\mathrm{EFW}>95^{\text {th }}$ centile in the prediction of mode of delivery by the term scan. The sensitivity, specificity, PPV, NPV and accuracy of EFW $>95^{\text {th }}$ centile was $33 \%, 72 \%, 95.73 \%, 5.35 \%$ and $34.95 \%$ respectively while it was $59 \%, 80 \%, 98.25 \%, 9.31 \%$ and $60.05 \%$ respectively for $\mathrm{HC}>95^{\text {th }}$ centile.

\section{CONCLUSION}

A large head circumference is more strongly associated with Caesarean section, than a higher estimated fetal weight. Prenatal determination of head circumference in predicting vaginal or caesarean delivery may go a long way of advising, planning and managing women with a macrosomic fetus. Prospective studies to give cut-offs of head circumference applicable to the Indian subcontinent, beyond which vaginal delivery is more hazardous than beneficial are recommended.

Funding: No funding sources Conflict of interest: None declared

Ethical approval: The study was approved by the Institutional Ethics Committee 


\section{REFERENCES}

1. Zandvakili F, Rezaie M, Shahoei R, Roshani D. Maternal outcomes associated with caesarean versus vaginal delivery. J Clin Diagnostic. 2017;11:QC01-4.

2. Shams-Beyranvand M. Predictors of caesarean section-a cross-sectional study in Hungary. J Matern Fetal Neonatal Med. 2020;45:52-9.

3. Renes L, Barka N, Gyurkovits Z, Paulik E, Nemeth G, Orvos H. Predictors of caesarean section - a crosssectional study in Hungary.J Matern Fetal Neonatal Med. 2018;31(3):320-4.

4. Benjamin SJ, Daniel AB, Kamath A, Ramkumar V. Anthropometric measurements as predictors of cephalopelvic disproportion. Acta Obstet Gynecol Scand. 2012; 91:122-7.

5. Khan MN, Islam MM, Shariff AA, Alm MM, Rahman MM. Socio-demographic predictors and average annual rates of caesarean section in Banglaesh between 2004 and 2014. Plos ONE. 2017;12(5):e0177579.

6. Froehlich RJ, Sandoval G, Bailit JL, GrobmanWA, Reddy UM, wapner RJ, et al. MSCE, for the eunice kennedy shriver national institute of child health and human development (NICHD) maternal- fetal medicine units (mfmu)network. association of recorded estimated fetal weight and caesarean delivery in attempted vaginal delivery at term. Obstet Gynecol. 2016 ;128(3):487-94.

7. Temerinac D, ChenXI, Sutterlin M, Kehl S. Influence of fetal birth weight on caesearean sectionrate and fetal outcomes after induction of labour. In Vivo. 2015;29(5):519-24.

8. De Vries B, Bryce B, Zandanova T, Ting J, Kelly P, Phipps H, Hyett JA. Is neonatal head circumference related to Ceasarean section for failure to progress? Aust N Z J Ostet Gynaecol. 2016;(6);571-7.

9. Lipschuetz M, Cohen SM, Ein-Mor E. A large head circumference is more strongly associated with unplanned cesarean or instrumental delivery and neonatal complications than high birthweight. Am J Obstet Gynecol. 2015;213:833.e1-12.

Cite this article as: Shettian N, Pitty N.

Fetal head circumference versus fetal weight at term as a predictor of labour outcome. Int J Reprod Contracept Obstet Gynecol 2022;11:201-5. 